\title{
Pengaruh Strategi Konflik Kognitif Ditinjau dari Kemampuan Awal Siswa untuk Mengurangi Miskonsepsi pada Materi Gelombang Mekanik
}

\author{
Nurwidya Hasanah ${ }^{1}$, Arif Hidayat ${ }^{1}$, Supriyono Koeshandayanto ${ }^{1}$ \\ ${ }^{1}$ Pendidikan Fisika-Universitas Negeri Malang
}

\begin{tabular}{l}
\hline \hline INFO ARTIKEL \\
\hline Riwayat Artikel: \\
Diterima: 11-12-2019 \\
Disetujui: 14-05-2020 \\
\hline
\end{tabular}

\section{Kata kunci:}

misconception; mechanical waves; cognitive conflict; miskonsepsi; gelombang mekanik; konflik kognitif

ABSTRAK
Abstract: This research was focused on the influence of the strategy of cognitive
conflict based on the students pre-test to reduce misconceptions on the concept of
mechanical wave. Method which is used in the research was quasi-experiment. The
research used two subjects which are experiment class and controlled class. Each
classes have 32 students who have same abilities based on their pre-test scores. To
analyze the data, Anacova was used for statistical analyzing. The result of this research
showed that the strategy of cognitive conflict successfully reduced the misconceptions
of the students.
Abstrak: Tujuan penelitian ini adalah mengetahui strategi konflik kognitif ditinjau dari
kemampuan awal siswa untuk mengurangi miskonsepsi pada materi gelombang
mekanik. Metode penelitian ini menggunakan kuasi eksperimen. Subjek penelitian kelas
eksperimen dan kelas kontrol dengan jumlaah 32 siswa seiap kelasnya yang mempunyai
rata-rata kemampuan awal sama. Data diolah dengan menggunakan analisis anacova.
Hasil penelitian menunjukkan bahwa kelompok yang diberi perlakuan dengan strategi
konflik kognitif mengalami penurunan miskonsepsi yang lebih tinggi daripada
kelompok yang dikontrol, dan siswa yang mempunyai kemampuan awal yang tinggi
pun juga mengalami penurunan miskonsepsi lebih tinggi daripada siswa yang
mempunyai kemampuan awal yang rendah.

Alamat Korespondensi:

Nurwidya Hasanah

Pendidikan Fisika

Universitas Negeri Malang

Jalan Semarang 5 Malang

E-mail: nurwidyahasanah@gmail.com

Pendidikan nasional mempunyai tujuan dalam mencerdaskan peserta didik, salah satunya dengan mengembangkan Kurikulum 2013 dengan membentuk pendidik yang menguasai konsep. Untuk mencapai tujuan tersebut, maka dirancang dengan berbagai cara agar siswa dapat mengembangkan keterampilanya, sikapnya maupun pengetahuan yang dimiliki untuk membangun pola pikir kreatif dan pemahaman konsep yang tinggi (Kemendikbud, 2013). Pendekatan yang digunakan dalam setiap pembelajaran, termasuk pembelajaran fisika di SMA menggunakan pendekatan saintifik dengan cara pengamatan, bertanya, berpikir, mengomunikasikan, dan menilai atau memahami materi yang telah diajarkan. Kesalahpahaman dan kesulitan dalam mekanika dijelaskan berdasarkan studi masa lalu dalam pendidikan sains (Daud, 2015).

Miskonsepsi yang dialami oleh siswa sangat tidak terduga (Amry, Rahayu, Yahmin, 2017; Parastuti, Suharti, Ibnu, 2016). Pengetahuan konsep siswa terkadang ada yang sama atau beda dengan teori ilmuan karena pengetahuan awal siswa berpengaruh dalam mengonstruksi pengetahuan baru. Berbagai konsepsi ini akan berpengaruh dalam proses memahami konsep-konsep fisika dan memecahkan masalah (Allen \& Coole, 2012). Permasalahan yang sering terjadi dalam pmbelajaran fisika adalah masalah kesalapahaman dan rendahnya pemahaman konsep (Laksana, 2016; Mufit, Festiyed, Fauzan, \& Lufri, 2018). Proses berubahnya suatu pengetahuan awal yang semula tidak sesuai dengan para ahli menjadi pengetahuan baru yang benar secara ilmiah merupakan perubahan konseptual (Jayanti, Wartono, Sutopo, 2016; Sani \& Aulia, 2018; Setyaningtyas, Dwiyana, Muksar, 2018). Untuk dapat meningkatkan pemahaman konsep dan meminimalisir terjadinya miskonsepsi dibutuhkan strategi yang memaksa siswa untuk membangun konflik konsepsi dalam benaknya. Strategi tersebut dapat diterapkan dengan bantuan guru sebagai fasilitator menciptakan suatu konflik konsepsi sehingga siswa melakukan proses asimilasi dan akomodasi konsep untuk membentuk sebuah pemahaman konsep yang tepat, benar dan konsisten. Sebuah strategi pembelajaran menjadi intervensi tepat guna setelah diintegrasikan dalam sebuah model pembelajaran. Dengan karakteristiknya, pembelajaran inkuiri ini diintegrasikan dengan strategi konflik kognitif sehingga menjadi intervensi yang tepat guna untuk diterapkan pada materi gelombang, dimana siswa dihadapkan kepada masalah autentik dan kontekstual untuk mengurangi miskonsepsi. 
Kesalahpahaman dikenal sebagai penghalang bagi siswa dalam belajar sains. Beberapa topik dalam pembelajaran sains selalu memberikan kesalahpahaman kepada siswa pemula, dan ada berbagai macam penilaian diagnostik yang digunakan oleh peneliti untuk mengidentifikasi kesalahpahaman siswa dalam sains. Penelitian ini memberikan informasi tentang ikhtisar topik umum yang biasanya siswa dapatkan kesalahpahaman dalam sains dan penilaian diagnostik yang digunakan untuk mengidentifikasi kesalahpahaman siswa dalam sains. Ulasan ini juga menyediakan perbandingan setiap instrumen dengan kelemahan dan kekuatan yang ditinjau dari total 111 artikel yang telah diterbitkan dari tahun 2015 hingga 2019 dalam jurnal terkemuka yang memiliki topik kesalahpahaman siswa dalam sains. Studi ini mengungkapkan bahwa 33 konsep fisika, 12 kimia, dan 15 biologi dalam sains yang terutama menyebabkan kesalahpahaman pada siswa. Lebih lanjut, ditemukan bahwa wawancara $(10,74 \%)$, tes pilihan ganda sederhana $(32,23 \%)$ dan tes beberapa tingkat $(33,06 \%)$, dan tes terbuka $(23,97 \%)$ umumnya digunakan sebagai tes diagnostik. Namun, setiap jenis tes memiliki kelebihan dan kekurangan dibandingkan yang lain ketika digunakan dalam menilai konsepsi siswa. Pengguna ahli seperti guru dan peneliti harus sadar ketika menggunakan penilaian diagnostik dalam proses pembelajaran, kecuali untuk membangun konsepsi siswa (2019; wati, 2018).

Kesalahpahaman adalah keyakinan yang bertentangan dengan pengetahuan ilmiah yang diterima tetapi tampaknya didukung oleh argument yang masuk akal. Kesalahpahaman dalam fisika membuktikan kurangnya pengakuan terhadap korelasi fisik yang ada, tetapi ide-ide yang tidak tepat ditemukan ditempatnya (Kuczmann, n.d.; Pulsifer, 2018). Kesalahpahaman berasal dari pengetahuan sebelumnya tentang pengalaman shari-hari atau yang diperoleh dari sekolah (A'yun, 2017; C Madu, 2015). Indikasi masalah kesalahpahaman ini adalah hasil belajar siswa tidak mencapai ketuntasan belajar (Akmam, 2018; Lee \& $\mathrm{Yi}, 2013)$.

Dalam pemecahan masalah dan pengajuan pertanyaan, peserta didik yang mempunyai pengetahuan awal tinggi lebih mudah mengembangkanya dibandingkan peserta didik yang berkemampuan awal rendah (Irawati, 2014) sehingga memengaruhi proses belajar siswa. Setiap siswa yang belajar materi baru akan ditentukan oleh kemampuan awalnya dalam proses pembelajarannya nanti (Sweller, Ayres, \& Kalyuga, 2011). Srategi konflik kognitif merupakan salah satu strategi yang mampu meningkatkan pemahaman konsep sehingga bias mengatasi miskonsepsi siswa. Perubahan jaringan konsep ini yang akan mendorong siswa untuk mengasimilasikan dan mengakomodasikan pengetahuan baru yang didapat (Goverover, n.d.). Menurut Supliadi ketika pengetahuan seseorang bertambah maka akan terjadi keseimbangan pengeahuan yang mana asimilasi dan akomodasi akan berambah. Euwe Van Den Berg dalam penelitiannya menjelaskan bahwa miskonsepsi dalam pembelajaran fisika mampu teratasi dengan strategi konflik kognitif.

Interaksi yang terjadi antar siswa saat praktikum dan diskusi yang baik akan mendorong perkembangan kognitif dan perkembangan kreativitas siswa sehingga mampu membentuk kebiasaan cara berpikir siswa dengan cara mengoptimalkan dan mengaplikasikan segala potensi yang dimilikinya. Terdapat tiga domain dalam metode inkuiri (1) siswa harus memiliki kesempatan untuk merancang penyelidikan berorientasi ilmiah melalui pertanyaan yang diuji oleh siswa; (2) siswa akan bekerja dalam kelompok kecil dan merancang prosedur percobaan untuk menjawab pertanyaan tersebut; (3) siswa akan berbagi temuan yang diperoleh dengan teman sebaya. Ketiga domain tersebut dapat dimanfaatkan untuk memfasilitasi kreativitas siswa (Barrow, 2010). Kesulitan yang ditemui dalam materi gelombang mekanik juga ditemukan di kelas XII MIA-3 SMAN 7 Malang. Berdasarkan hasil observasi awal pelajaran fisika di kelas XII MIA-3 di SMAN 7 Malang materi gelombang, terdapat $21 \%$ murid yang memperoleh nilai diatas KKM. Hasil tersebut didukung oleh wawancara awal yang dilakukan kepada guru fisika kelas XII SMAN 7 Malang bahwa metode yang digunakan selama pembelajaran masih menggunakan metode ceramah, latihan soal, dan guru seringkali memberikan rumus utama atau rumus penting yang sering digunakan selama ujian sehingga penguasaan konsep siswa menjadi kurang.

Pada tahun 2009 disajikan gelombang mekanik survei konseptual (MWCS), yang merupakan tes paling penting yang dirancang untuk mengevaluasi pemahaman siswa (Tongchai, Sharma, Jhonston, Arayanthanitkul, \& Soankwan, 2009). Topik gelombang tidak kalah penting, namun kurang dikenal dibandingkan topik mekanika atau kinematika, listrik dan magnet. Salah satu materi penting yang harus dikuasi dengan baik yakni Gelombang (Jumadin, Hidayat, Sutopo, 2017). Berbeda dengan gaya dan gerak, peneliti kurang tertarik membahas fenomena perambatan gelombang (Sutopo, 2016). Beberapa penelitian miskonsepsi siswa terkait topik gelombang antara lain telah dilakukan dengan fokus mengkaji miskonsepsi pada efek doppler, dan menyelidiki tentang frekuensi alamiah yang dihasilkan instrumen yang memanfaatkan kolom udara sebagai sumber bunyi (Kempston, 2010) Materi gelombang mekanik dapat dijadikan instrument untuk mengukur miskonsepsi siswa dengan menggunakan isomophic two tier. Guru harus mengidentifikasi siswa mereka dengan penilaian diagnostik (Alwan, 2011). Soal isomorfik menghindarkan jawaban siswa yang sekedar tebakan. Mechanics Isomorphic Problem Pairs pada topik mekanika, dan MWCS telah dikembangkan untuk menganalisis miskonsepsi pada siswa. (Singh, 2008).

Beberapa peneliti membuat pengembangan soal isomorfik untuk mendiagnosa peserta didik yang mengalami miskonsepsi, seperti yang dikembangkan Agnes (2016) dengan judul "Pengembangan Tes Diagnostik Pilihan Ganda Isomorfik pada Materi Gelombang." Sehingga peneliti ingin mengetahui efektivitas pendekatan konflik kognitif pada matrei gelombang untuk mengurangi miskonsepsi siswa. Berdasarkan keadaan di atas, peneliti ingin meneliti "Pengaruh Strategi Konflik Kognitif ditinjau dari Kemampuan Awal Siswa untuk Mengurangi Miskonsepsi pada Materi Gelombang Mekanik." 


\section{METODE}

Penelitian ini menggunakan jenis penelitian eksperimen. Pemilihan desain ini dikarenakan di sekolah sampel kelasnya sudah terbentuk. Ciri Quasi Experimental itu mempunyai kelompok control yang tidak sepenuhnya dapat mengontrol variabel luar yang memengaruhi kegiatan pnelitian dengan melibatkan validator sebagai eksperimental yang sesungguhnya (Sugiyono, 2015). Subjek penelitian ini pada siswa kelas XI SMA Negeri 7 Malang. Pengambilan sampel menggunakan teknik purposive sampling dengan pertimbangan kelas eksperimen dan kelas kontrol masing-masing berjumlah 32 siswa yang mempunyai ratarata kemampuan awal sama, yakni tiap kelas terdapat siswa berkemampuan awal tinggi dan berkemampuan awal rendah.

Penelitian ini menggunakan instrumen pretes dan posttes diagnosa miskonsepsi berbentuk uraian dan pilihan ganda. Sebelum diberi perlakuan, siswa diberi tes kemampuan awal (pretest) baik pada kelas eksperimen maupun kelas kontrol. Kelas eksperimen diberi model pembelajaran berbasis masalah dengan strategi konflik kognitif, sedangkan kelas kontrol diberi pembelajaran ceramah, kemudian di akhir pembelajaran diberi tes miskonsepsi (posttest). Data yang dikumpulkan diolah dengan statistik inferensial teknik ANCOVA. Soal yang digunakan sebanyak lima soal two tier untuk mendiagnosis siswa yang mengalami miskonsepsi pada materi gelombang mekanik. Rumus Kuder-Richardson 20 digunakan untuk mengukur reabilitas soal multiple choice (Arikunto, 2012). Bantuan online di program SPSS Statistics 17.0 dijelaskan bahwa apabila data berbentuk dikotomi, maka koefisien KR20 ekuivalen dengan rumus korelasi Cronbach's Alpha (Topic SPSS Statistics 17.0).

Tabel 1. Distribusi Sampel

\begin{tabular}{lcc}
\hline Sampel & Experiment Group & Control Group \\
\hline Jumlah & 32 & 32 \\
Kemampuan awal tinggi & 16 & 16 \\
Kemampuan awal rendah & 16 & 16 \\
\hline
\end{tabular}

Hasil prestasi belajar siswa yang diperoleh dari tes kemampuan awal dapat dikelompokkan menjadi tiga bagian, yakni sisa berkemampuan tinggi, sedang, dan rendah ditetapkan sebagai berikut (Dirjen Dikti, 2012):

1. Kemampuan Awal Tinggi dengan skor $\geq 70 \%$

2. Kemampuan Awal Sedang, skor $50 \% \leq$ skor $<70 \%$

3. Kemampuan Awal Rendah, skor $<50 \%$

Berdasarkan kriteria di atas, pengelompokkan siswa yang berkemampuan awal tinggi, sedang, dan rendah dapat dilihat pada tabel 2 .

Tabel 2. Pengelompokkan Kemampuan Awal Siswa

\begin{tabular}{ll}
\hline \multicolumn{1}{c}{ Kelompok } & \multicolumn{1}{c}{ Nilai } \\
\hline Tinggi & $\geq 70$ \\
Rendah & $50 \leq$ Skor $<70$ \\
Rendah & $<50$ \\
\hline
\end{tabular}

\section{HASIL}

Hasil penelitian pada materi Gelombang dengan strategi konflik kogitif di SMAN 7 Malang, meliputi (1) terdapat perbedaan pembelajaran pada kelompok yang menerapkan model based larning dengan strategi konflik kognitif dan kelompok pembelajaran konvensional (ceramah) dan (2) miskonsepsi siswa berkemampuan awal tinggi lebih tinggi dibandingkan siswa yang berkemampuan awal rendah. Tabel 3 menunjukkan hasil rekapitulasi Ancova melalui SPSS.

Tabel 3. Rekapitulasi Hasil ANCOVA

\begin{tabular}{lccccc}
\hline Source & Type III Sum of Squares & $\boldsymbol{d f}$ & Mean Square & $\boldsymbol{F}$ & Sig \\
\hline Correced Model & $7067.674^{*}$ & 4 & 1766.918 & 28.155 & .00 \\
Inercept & 1812.918 & 1 & 1812.918 & 28.880 & .000 \\
Pretest & 301.764 & 1 & 301.764 & 4.808 & .000 \\
Pembelajaran & 1084.679 & 1 & 1084.679 & 17.284 & .000 \\
Kemampuan awal & 904.919 & 1 & 904.919 & 14,419 & .001 \\
Pembelajaran Kemampuan awal & 6.387 & 1 & 6.387 & .102 & .752 \\
Error & 1094.443 & 27 & 62.757 & & \\
\hline Total & 117904.709 & 32 & & & \\
Corrected Total & 8762.117 & 31 & & & \\
\hline
\end{tabular}

a. R Squared $=.807$ (Adjused R Squared $=.778$ 
Untuk pengujian hipotesis I, berdasarkan tabel 3 diatas diperoleh nilai $F_{\text {hitung }}=17.284$ dengan angka signifikan 0.000 kurang dari 0.05. Sehingga dapat diinterpretasikan bahwa model pembelajaran berbasis masalah dengan strategi konflik kognitif sangat berpengaruh dalam hasil prestasi belajar siswa dalam hal penurunan miskonsesi pada materi Gelombang ini lebih besar dibandingkan kelompok belajar model konvensional di SMAN 7 Malang.

Untuk pengujian hipotesis II, berdasarkan tabel 3 diatas diperoleh nilai $F_{\text {hitung }}=14.419$ dengan angka signifikansi 0.001 lebih kecil dari 0.05 sehingga dapat diinterpretasikan bahwa dengan pengendalian variabel kovariat kemampuan awal siswa, hasilnya menunjukkan bahwa kelompok siswa berkmampuan awal tinggi lebih besar dibandingkan dengan siswa berkemampuan awal rendah, begitu pula siswa yang berada di kelas konvensional di SMAN 7 Malang.

Siswa yang mempunyai kemampuan awal tinggi akan mudah dalam menangkap pengetahuan yang baru dan akan mengurangi kesalahpahaman konsep. Apabila siswa berkemampuan awal beda dan diberikan perlakuan atau model pembelajaran yang sama, maka ketercapaian hasil belajar akan linear dengan kemampuan awal yang dimilikinya (Nasution, 2010).

\section{PEMBAHASAN}

Berdasarkan hasil uji ancova, dengan pengendalian variabel kovariat kemampuan awal siswa, yang hasilnya siswa yang belajar dengan model berbasis masalah menggunakan strategi konflik kognitif akan mengalami penurunan miskonsepsi dan hasil belajar yang besar dibandingkan dengan siswa yang belajar dengan model ceramah. Hal yang sama terjadi pada siswa berkemampuan awal tinggi menghasilkan prestasi belajar yang besar dibanding siswa berkemampuan awal rendah pada materi gelombang mekanik di SMAN 7 Malang. Keaktifan siswa didalam pembelajaran based learning dengan strategi konflik kognitif membawa dampak positif terhadap penurunan miskonsepsi siswa daripada pembelajaran konvensional. Siswa dengan kemampuan awal tinggi akan lebih mudah untuk menghubungkan pengetahuan yang diperoleh sebelumnya dengan pengetahuan yang baru. Siswa yang mempunyai kemampuan awal tinggi akan mudah dalam mengintegrasikan pengetahuan lama dengan pengetahuan baru untuk memecahkan permasalahan kehidupan sehari-hari sehingga penurunan miskonsepsi tercapai.

Penelitian sebelumnya memperoleh bahwa kemampuan awal dalam proses pembelajaran akan mempermudah siswa dalam memahami konsep yang baru dan menghubungkan antar konsep (McBride, Rebello, \& Zollman, 2010). Sementara pada penelitian lain berkaitan pengaruh kemampuan awal terhadap kemampuan memecahkan masalah mengungkapkan bahwa siswa yang berkemampuan awal tinggi akan memudahkan siswa dalam memecahkan masalah (Chang, 2008). Kemampuan awal yang tinggi akan menguntungkan siswa dalam menghadapi posttest. Tingkat keberhasilan pembelajaran bagi siswa tergantung kemampuan awal (Pritchard, Lee, \& Bao, 2008). Dari penelitian diungkapkan bahwa hasil prestasi belajar siswa berkemampuan awal tinggi lebih tinggi dibandingkan siswa berkemampuan awal rendah (Herawati, Redjeki, \& Mulyani, 2013). Siswa yang mempunyai kemampuan awal tinggi akan mudah dalam menangkap pengetahuan yang baru. Jika siswa memiliki kemampuan awal yang berbeda kemudian diberikan perlakuan atau model pembelajaran yang sama, maka ketercapaian hasil belajar akan linear dengan kemampuan awal yang dimilikinya (Nasution, 2010).

Keseringan seorang pelajar, baik peserta didik maupun mahasiswa akan mengalami kesulitan mengonstruk pengetahuannya jika tidak mempunyai hubungan antara pengetahuan awal dengan pengetahuan barunya (Trianto, 2014). Kemampuan awal dapat dijadikan sebagai dasar siswa dalam memahami konsep pengetahuan sains. Kemampuan awal merupakan faktor utama yang memengaruhi keberhasilan proses pembelajaran (Yarden \& Yarden, 2010). Keberhasilan pembelajaran dipengaruhi oleh kemampuan awal yang dimiliki siswa. Semakin baik kemampuan awal siswa, maka semakin mudah siswa dalam mempelajari konsep yang baru. Siswa yang berkemampuan awal tinggi akan mudah mengaitkan konsep lama dengan konsep baru yang dipelajari.

Keberhasilan observasi sains dapat ditentukan dari kemampuan awal siswa (Miller, Lastry, Chu, \& Mazur, 2013). Siswa yang mempunyai kemampuan awal tinggi mudah untuk mengonstruksi pengetahuan melalui observasi. Dengan pemahaman konsep sains siswa yang baik memberi kontribusi yang besar terhadap ketercapaian indikator penurunan miskonsepsi siswa dalam pembelajaran. Dengan demikian, memperhatikan karakteristik peserta didik terutama kemampuan awal peserta didik sebelum menerapkan suatu pembelajaran tertentu sangatlah penting dilakukan. Hal ini bertujuan agar pembelajaran yang dilaksanakan dapat lebih bermakna.

Berdasarkan hasil uji ancova, penurunan miskonsepsi siswa di kelas eksperimen lebih tinggi dibanding kelas kontrol yang belajar dengan model ceramah. Hal ini dapat terjadi karena dalam mengkonstruk pengetahuan barunya, siswa dapat dibantu dengan sebuah konflik yang mengena pada kognitifnya, tidak hanya melalui diskusi dan interaksi dengan teman sebaya, tetapi juga melalui proses diskusi yang membantu siswa dalam proses investigasi (praktikum). Tiga langkah yang harus ditempuh agar pembelajaran strategi konflik kognitif ini berhasil, meliputi (1) sebelum memulai pembelajaran, siswa diidentifikasi terlebih dahulu mengenai konsep agar terjadi disequilibrasi atau ketidakseimbangan, (2) memberikan masalah agar tercipta sebuah konflik dalam pengetahuanya terjadi reformulasi and recall information, dan (3) memberikan latihan berupa pertanyaan rekonstruksi.

Strategi konflik kognitif pernah digunakan untuk menjelaskan konsep benda tenggelam dan terapung (Hadjiachilleous, Valanides, \& Angeli, 2013). Hasil yang signifikan dari penelitian tersebut adalah siswa mampu mencapai peningkatan pemahaman konsep sehingga miskonsepsi berkurang. Siswa memperoleh lingkungan sangat baik dari pembelajaran strategi konflik kognitif ini karena bisa terlibat penuh dalam berdiskusi dan juga berinteraksi dengan teman sebaya. Pembelajaran yang 
diberikan ini tidak hanya memengaruhi kemampuan kognitif saja, tetapi juga berpengaruh terhadap tingkat emosional siswa. Pada kelas kontrol, sebagian besar siswa sangat hiperaktif sehingga sering berbicara sendiri dengan temannya saat pembelajaran. Pembelajaran yang terjadi pada kelas konvensional dengan metode ceramah. Meskipun ada sesi diskusi dan tanya jawab, namun sedikit siswa yang tertarik dan memilih untuk becanda bahkan berbicara sendiri dengan teman sebangkunya. Hal ini dikarenakan model yang monoton membuat siswa tidak bersemangat dalam belajar mencari ilmu. Siswa yang aktif dapat dihitung jari sehingga siswa tidak mampu menyelesaikan soal dan sedikit menguasai materi yang disampaikan. Nilai post-test kelas kontrol juga hanya mengalami sedikit peningkatan sehingga hasil belajar yang diperoleh kurang maksimal.

Hasil penelitian ini menyimpulkan bahwa pembelajaran dengan cara membenturkan permasalahan dalam struktur kognitifnya akan lebih efektif karena siswa mampu menyelesaikan masalah sendiri dibandingkan dengan pembelajaran model biasa atau ceramah yang dimana siswa hanya diam mendengarkan saja, akan terlihat monoton dan melelahkan. Salah satu tugas guru atau peneliti adalah mampu menerapkan pembelajaran dengan baik dan maksimal dalam pembelajaran yang digunakan. Dengan demikian, guru mampu menghasilkan hasil yang diharapkan, siswa memahami materi yang disampaikan dan dapat berbagi ilmu dengan teman sebaya sesuai apa yang didapatkan.

\section{SIMPULAN}

Berdasarkan hasil analisis data di atas dapat diambil simpulan. Pertama, terdapat pengaruh hasil belajar siswa dan penurunan miskonsepsi yang menggunakan model based learning dengan strategi konflik kognitif lebih tinggi daripadakelompok siswa yang belajar dengan pembelajaran konvensional pada materi gelombang mekanik di SMAN 7 Malang. Kedua, penurunan miskonsepsi peserta didik yang berkemampuan awal tinggi lebih besar dibandingkan peserta didik berkemampuan awal rendah pada materi gelombang mekanik di SMAN 7 Malang. Peneliti lain dapat menggunakan model pembelajaran lain untuk melakukan penelitian penurunan miskonsepsi siswa atau dapat menggunakan materi lain dengan model pembelajaran yang sama.

\section{DAFTAR RUJUKAN}

Akmam, A. (2018). Influence of Learning Strategy of Cognitive Conflict on Student Misconception in Computational Physics Course. IOP Conference Series: Materials Science and Engineering, 335. https://doi.org/10.1088/1757$899 X / 335 / 1 / 012074$

Allen, M., \& Coole, H. (2012). Experimenter Confirmation Bias and The Correction of Science Misconceptions. Journal of Science Teacher Education, 23(4), 387-405.

Alwan, A. A. (2011). Misconception of Heat and Temperature among Physics Students. International Conference on Education and Educational Psychology, 12, 600-614. https://doi.org/doi.org/10.1016/j.sbspro.2011.02.074

Amry, U. W., Rahayu, S., \& Yahmin. (2017). Analisis Miskonsepsi Asam Basa pada Pembelajaran Konvensional dan Dual Situated Learning Model (DSLM). Jurnal Pendidikan: Teori, Penelitian, dan Pengembangan, 2(3), 385-391.

Arikunto, S. (2012). Dasar-Dasar Evaluasi Pendidikan. Jakarta: PT. Bumi Aksara.

A'yun, K. (2017). Reduction of Cognitive Conflict and Learning Style Impact Towards Student-Teacher's Misconception Load. AIP Conference Proceedings, 1868. https://doi.org/doi.org/10.1063/1.4995103

Barrow, L. H. (2010). Encouraging Creativity with Scientific Inquiry. Creative Education, 1(1), 1-6.

C Madu, B. (2015). Effects of Cognitive Conflict Instructional Strategy on Students' Conceptual Change in Temperature and Heat. SAGE Journals, 5(3). https://doi.org/10.1177/2158244015594662

Chang, C. Y. (2008). Does Problem Solving Prior Knowledge Reasoning Skills in Earth Science? An Exploratory Study. The Journal of Educational Resesarch, 40(2), 103-106.

Daud, N. S. (2015). Misconception and Difficulties in Introductory Physics Among High School and University Students: An Overview in Mechanics. Journal of Science, Mathematics and Technology, 2, 34-47.

Dirjen Dikti. (2012). Pengembangan dan Penyusunan Kurikulum Pendidikan Tinggi (KPT) Pendekatan Kurikulum Berbasis Kompetensi (KBK) dan Pendidikan Berbasis Capaian (PBC). Jakarta: Kementerian Pendidikan dan Kebudayaan Direktorat Jenderal Pendidikan Tinggi Direktorat Pembelajaran dan Kemahasiswaan.

Goverover, Y. (n.d.). Brief International Cognitive Assessment for Multiple Sclerosis (BICAMS) and performance of everyday life tasks: Actual Reality. SAGE Journals, 2015. https://doi.org/doi.org/10.1177/1352458515593637

Hadjiachilleous, S., Valanides, N., \& Angeli, C. (2013). The Impact of Cognitive and affective Aspects of Cognitive Conflict on Learners Conceptual Change about Floating and Sinking. Research in Science \& Technological Education, 31(2), 133152.

Herawati, R. F., Redjeki, T., \& Mulyani, S. (2013). Pembelajaran Kimia Berbasis Multiple Representasi ditinjau dari Kemampuan Awal terhadap Prestasi Belajar Laju Reaksi SMA Negeri 1 Karanganyar. Jurnal Pendidikan Kimia, 2(2), 20-42.

Irawati, R. K. (2014). Pengaruh Model Problem Posing dan Problem Solving serta Kemampuan Awal terhadap Hasil Belajar Siswa. Jurnal Pendidikan Sains, 2(4), 184-192.

Jayanti, I. B. R., Wartono., \& Sutopo. (2016). Dampak Program Resitasi Terhadap Perubahan Konseptual Mahasiswa pada Topik Hukum III Newton. Jurnal Pendidikan: Teori, Penelitian, dan Pengembangan, 1(2), 256-264. 
Jumadin, L., Hidayat, A., \& Sutopo. (2017). Perlunya Pembelajaran Modelling Instruction pada Materi Gelombang. Jurnal Pendidikan: Teori, Penelitian, dan Pengembangan, 2(3), 325-330.

Kemendikbud. (2013). Peraturan Menteri Pendidikan dan Kebudayaan RI No. 70 Tahun 2013 tentang Kerangka Dasar dan Struktur Kurikulum Sekolah Menengah Kejuruan/Madrasah Aliah Kejuruan. Jakarta: Kemendikbud.

Kempston. (2010). The Doppler Effect and How to Use it for Measurement. Retrieved from http://www.edes.bris.ac.uk/year4/RandC4/7MinPresentations/nkDoppler.Doc

Kuczmann, I. (n.d.). The Structure of Knowledge and Students' Misconceptions in Physics. AIP Conference Proceedings, 1916(1), 2017. https://doi.org/doi.org/10.1063/1.5017454

Laksana, D. N. L. (2016). Miskonsepsi Dalam Materi IPA Sekolah Dasar. Jurnal Pendidikan Indonesia, 5(2), $166-175$.

Lee, G., \& Yi, J. (2013). Where Cognitive Conflict Arises From?: The Structure of Creating Cognitive Conflict. International Journal of Science and Mathematics Education, 11(3), 601-623.

McBride, A. I., Rebello, N. S., \& Zollman, D. (2010). Method for Analyzing Students. Utilization of Prior Physics Learning in New Contexts. Physical Review Special Topic-Physics Education Research, 6(2), 1-7.

Miller, K., Lastry, N., Chu, K., \& Mazur, E. (2013). Role of Physics Lecture Demonstrations in Conceptual Learning. Physical Review Special Topic Physics Education Research, 9(2), 1-5.

Mufit, F., \& Festiyed, F., Fauzan, A., \& Lufri, L. (2018). Impact of Learning Model Based on Cognitive Conflict Toward Student's Conceptual Understanding. IOP Conf. Series: Materials Science and Engineering. https://doi.org/10.1088/1757-899X/335/1/012072

Nasution. (2010). Kurikulum dan Pengajaran. Jakarta: Bumi Aksara.

Parastuti, W. I., Suharti., \& Ibnu, S. (2016). Miskonsepsi Siswa pada Materi Larutan Buffer. Jurnal Pendidikan: Teori, Penelitian, dan Pengembangan, 1(12), 2307-2313.

Pritchard, D. E., Lee, Y. J., \& Bao, L. (2008). Mathematical Learning Models That Depend on Prior Knowledge and Instructional Strategies. Physical Review Special Topic-Physics Education Research, 4(2), 1-8.

Pulsifer, M. B. (2018). Cognitive and Adaptive Outcomes After Proton Radiation for Pediatric Patients with Brain Tumors. International Journal of Radiation Oncology Biology Physics, 102(2), 391-398. https://doi.org/doi.org/10.1016/j.ijrobp.2018.05.069

Sani, R. A., \& Aulia, R. (2018). Upaya Mengatasi Miskonsepsi Siswa dengan Menggunakan Model Pembelajaran Inquiry Training pada Materi Pokok Momentum dan Impuls di Kelas X SMA Negeri 3 Binjai Tahun Pelajaran 2017/2018. Jurnal Ikatan Alumni Fisika Universitas Negeri Medan, 4(3), 1-6.

Setyaningtyas, A. D., Dwiyana., \& Muksar, M. (2018). Miskonsepsi Siswa SMP Kelas IX pada Materi Bentuk Akar. Jurnal Pendidikan: Teori, Penelitian, dan Pengembangan, 3(6), 731-738.

Singh, C. (2008). Assessing student expertise in introductory physics with isomorphic problems. II. Effect of some potential factors on problem solving and transfer. Physical Review Special Topics-Physics Education Research, 4(1), 010105.

Soeharto. (2019). A Review of Students' Common Misconceptions in Science and Their Diagnostic Assessment Tools. Jurnal Pendidikan IPA Indonesia, 8(2), 247-266. https://doi.org/10.15294/jpii.v8i2.18649

Sugiyono. (2015). Metode Penelitian Pendidikan (Pendekatan Kuantitatif, Kualitatif, dan R\&D). Bandung: Alfabeta.

Sutopo, S. (2016). Pemahaman Mahasiswa tentang Konsep-Konsep Dasar Gelombang Mekanik. Jurnal Pendidikan Fisika Indonesia, 12(1), 41-53. https://doi.org/10.15294/jpfi.v12i1.4264

Sweller, J., Ayres, P., \& Kalyuga, S. (2011). Cognitive Load Theory. New York: Springer.

Tongchai, A., Sharma, M. D., Jhonston, I. D., Arayanthanitkul, K., \& Soankwan, C. (2009). Evaluating and Demonstrating the Use of a Conceptual Survey in Mechanical Waves. International Journal of Science Education, 31(18). https://doi.org/10.1080/09500690802389605

Trianto. (2014). Mendesain Model Pembelajaran Inovatif, Progresif, dan Kontekstual: Konsep, Landasan, dan Implementasinya pada Kurikulum 2013 (Kurikulum Tematik Integratif/KTI). Jakarta: Prenadamedia Group.

Wati, S. (2018). The Improvement of Mathematical Spatial Visualization Ability of Student through Cognitive Conflict. International Electronic Journal of Mathematics Education, 12(2), 155-165.

Yarden, H., \& Yarden, A. (2010). Learning Using Dynamic and Static Visualitations: Students 'Comprehension, Prior Knowledge and Conceptual Status of a Biotechnological Method. Res Science Education, 40, 375-402. 